\title{
1. International trade, human rights and policy space
}

\section{Thomas Cottier}

\section{THE CALL FOR POLICY SPACE}

The call for domestic policy space characterises recent debates on trade and investment in international economic law. In the wake of globalization, the creation of the World Trade Organization (WTO) and a number of new agreements, critics deplore the loss of policy space in domestic law and on national levels, in particular in developing countries. ${ }^{1}$ Governments, it is argued, are no longer able to pursue appropriate policies and are unduly restrained by international economic law in the pursuit of development and welfare and the realization of human rights. Trade liberalization is felt to be at the expense of jobs, a major cause of unemployment at home and an ever-increasing disparity of incomes. Moreover, governments are felt to be restrained from implementing appropriate food standards, and consumers are obliged to accept products, which domestically they do not allow, such as GMOs. Investment protection is felt to unduly restrict options to protect the livelihood of people affected. Intellectual property

1 See for example: Kevin P. Gallagher, ed., Putting Development First: The Importance of Policy Space in the WTO and International Financial Institutions (Chicago: The University of Chicago Press, 2005); P. Sai-wing Ho, "Arguing for Policy Space to Promote Development: Prebisch, Myrdal, and Singer" (2008) 42:2 Journal of Economic Issues 509; Shahrukh Rafi Khan, "WTO, IMF and the Closing of Development Policy Space for Low-Income Countries: A Call for Neo-Developmentalism" (2007) 28:6 Third World Quarterly 1073; Paul Alexander Haslam, "The Firm Rules: Multinational Corporations, Policy Space and Neoliberalism" (2007) 28:6 Third World Quarterly 1167; on trade regulation in particular see Bernard Hoekman, "Operationalizing the Concept of Policy Space in the WTO: Beyond Special and Differential Treatment" (2005) 8:2 Journal of International Economic Law 405; Kevin P. Gallagher, "Understanding Developing Country Resistance to the Doha Round" (2008) 15:1 Review of International Political Economy 62; Steven Bernstein and Erin Hannah, "NonState Global Standard Setting and the WTO: Legitimacy and the Need for Regulatory Space” (2008) 11:3 Journal of International Economic Law 575. 
standards are considered to be excessively imposing restrictions on regulation by international economic law, hindering development and access to essential goods. These arguments not only exist in relations between developing countries, emerging economies and industrialised countries; they equally dominate current debates among industrialised countries having social safety nets. The Comprehensive Economic and Trade Agreement (CETA) between Canada and the European Union is the subject of criticism as much as the currently negotiated Transatlantic Trade and Investment Partnership Agreement (TTIP) between the European Union (EU) and the United States. ${ }^{2}$

It would seem that trade liberalization as such has reached an end, facing the call for more domestic policy space and a less intrusive framework of international law than those based upon the WTO and the plus elements in the newer generation of preferential trade and investment agreements currently dominating international treaty making in the field. Conceptually, the motives for more domestic policy space are manifold and are voiced from different quarters of the political spectrum. They are nurtured by concern for protecting human rights. They are motivated by self-determination and democracy. They are motivated by cultural diversity, which globalization and its legal framework threaten to undermine. They are motivated by environmental concerns and the call for sustainable development, and less dependence on global markets and globalization. They are also motivated by national conservative agendas, populism exploiting fears of mass immigration, loss of national identity and partly by rent-seeking protectionism. A very mixed composition of motives adds up and may bring traditional modes of trade liberalization to a halt in coming years. This may show in cancelling existing agreements or refraining from entering into new ones. ${ }^{3}$ It may show in renegotiating existing agreements and provisions. It may show in refraining from policies of mutual recognition and harmonization of product and process standards.

While these efforts play out in political debates and decision-making, the pursuit of policy space also takes more nuanced forms by means of reinterpreting existing provisions in the process of case law-making. Interpretation of existing law amounts to the main function of human

2 Tereza Novotná, Mario Telò and Jean-Frédéric Morin, eds, The Politics of Transatlantic Trade Negotiations: TTIP in a Globalized World (Farnham: Ashgate, 2015).

3 This chapter is written in times witnessing ardent debates over whether Britain should leave the EU or whether Europe and the EU should enter the Transatlantic Trade and Investment Partnership Agreement (TTIP). 
rights courts, investment arbitration and WTO panels and the Appellate Body. Whether or not, these bodies infringe upon domestic prerogatives is a constant theme in the political discourse. All these developments can be analysed in terms of efforts to increase domestic policy space and to restrain the impact of public international law.

Policy space thus is mainly employed with the understanding of a lack of or insufficient levels of policy space granted to domestic law. It is expressed in terms of seeking enhanced exceptions, special and differential treatment or the development of what I called graduation, that is linking legal obligations incurred to economic indicators and thresholds. ${ }^{4}$

The issue whether there is too much policy space allocated to domestic law has hardly ever been raised and addressed in such terms. This is true for human rights, labour standards, investment and trade regulations alike. In political discourse, policy space is a one-way street. It campaigns for less international law and lower levels of intrusiveness. Policy space, however, looks somewhat different if we look at it from the point of view of regulatory theory and the doctrine of multilevel governance.

\section{MULTILEVEL GOVERNANCE AND POLICY SPACE}

The relationship between international law and domestic law is increasingly perceived as a matter of multilevel governance. ${ }^{5}$ This is the case both in analytical terms, looking at existing interdependencies, as well as in normative terms, developing a new constitutional framework to harness the process of globalization and enhanced interdependence. Building upon the traditions of federalism and the interplay of federal, sub-federal and local levels, regional law (EU law or, to a lesser extent, the North American Free Trade Agreement (NAFTA)) and global international law add additional layers of governance, which supplement existing and traditional structures of domestic law. While the formal distinction of domestic and international law remains, these additional layers share characteristics with domestic layers of constitutionalism, liberalism and

4 Thomas Cottier, "From Progressive Liberalization to Progressive Regulation in WTO Law" (2006) 9:4 Journal of International Economic Law 779.

5 See generally Simona Piattoni, The Theory of Multi-level Governance: Conceptual, Empirical, and Normative Challenges (Oxford: Oxford University Press, 2010). From a trade policy angle see Christian Joerges and Ernst-Ulrich Petersmann, eds, Constitutionalism, Multilevel Trade Governance and International Economic Law (Oxford: Hart Publishing, 2011). 
the welfare state. They share fundamental values, in particular human rights, non-discrimination and general principles of law. ${ }^{6}$ In the case of the EU as a new layer, a legal system, sui generis, emerged that also aspires to respond to the precepts of democratic governance. On the global level, especially the United Nations (UN) and other international organizations, in particular the Bretton Woods Institutions and the WTO, instruments mainly controlled by domestic executive powers draw their legitimacy from outputs and directions defined by democratically elected governments. Multilevel governance, for federalist countries in the tradition of democratic constitutionalism, amounts to what I called a "Five Storey House". ${ }^{7}$ Vertical checks and balances of power operate among the different levels of governance, offsetting state failures and allocating regulatory powers ideally suitable to produce appropriate public goods at appropriate levels of governance - local, sub-federal, federal, regional or global. It is the essence of what the late John Jackson called "Sovereignty-modern". ${ }^{8}$ It is essentially about allocation of regulatory and interpretive powers in the operation of the law.

In this framework, policy space amounts to an inherent and necessary component of regulatory theory. Ever since, it has been a feature of regulatory powers, defining autonomous areas or delegated powers by means of defining the density of legal norms, from legal principles to detailed regulation. Policy space is defined by the breadth of a norm and the level of detailed regulation. Open-textured norms, including general principles of law and human rights, inherently entail policy space, while detailed regulations do not. Likewise, authorities and courts of law enjoy policy space in applying and interpreting norms commensurate with the open or detailed structure of the norm at hand. ${ }^{9}$

But policy space is also inherent to all law as it defines allocation of

6 Thomas Cottier, "Multilayered Governance, Pluralism, and Moral Conflict" (2009) 16 Indiana Journal of Global Legal Studies 647.

7 Thomas Cottier, "Towards a Five Storey House" in Joerges and Petersmann (note 5 above) at 495; Thomas Cottier and Maya Hertig, "The Prospects of 21st Century Constitutionalism" in Armin von Bogdandy and Rüdiger Wolfrum, eds, Max Planck Yearbook of United Nations Law, vol. 7 (Max Planck Institute, 2003) 261.

8 John H. Jackson, Sovereignty, the WTO, and Changing Fundamentals of International Law (Cambridge: Cambridge University Press, 2006).

9 See Thomas Cottier and Lucia Satragno, "The Potential of Law and Legal Methodology in Monetary Affairs" in Thomas Cottier, Rosa M. Lastra, Christian Tietje and Lucia Satragno (eds), The Rule of Law in Monetary Affairs (Cambridge: Cambridge University Press, 2014) 411 at 421-6 discussing the essence of regulatory theory. 
powers between different levels of government. The principles of nondiscrimination in global law (national treatment and most favoured nation (MFN)) deploy comparable effects to interstate commerce clauses in the US Constitution and functionally equivalent norms in other constitutions; they all serve the purpose of creating level playing fields and fair conditions of competition and market access on and to subsequent levels of governance. ${ }^{10}$ The same is true for human rights guarantees protecting individuals within subsequent jurisdictions from violations by the authorities acting on that level of governance.

Finally, policy space indirectly shapes the relationship among parallel levels of governance, which in federacy and international law find themselves competing in regulatory terms. Policy space granted to subsequent jurisdictions allows for diverging and localised regulations, which in terms define the competitive relationship between subsequent jurisdictions on the same level. For example, autonomous powers to tax will be used differently and define competitive relations among different jurisdictions.

From this point of view, and other than in the political and economic discourse described above, policy space is a perfectly neutral term. It describes and defines the scope and degree of regulatory power assigned to a particular level of government within the overall regulatory system of the Five Storey House. The term does not define appropriate levels as such. It does not per se privilege domestic levels vis-à-vis international or regional law. It does not per se favour regulation over judicial law-making. It applies to all levels of governance alike as it encompasses configurations of discretion and decision-making powers granted to subsequent levels within the law. It entails configuration of full policy space in the absence of preceding norms up to zero policy space in configurations where a matter is exclusively regulated and shaped by a different, often superior layer of government.

Within these constellations, we find the normal configuration of shared policy space where a matter is partly addressed by one layer, but leaves room for differing regulations on a different layer of government. Normally, regulation is a matter of degree. The quest for appropriate policy space and allocation of powers and policy mixes is informed by overarching values and principles which seek to produce appropriate public goods, such as market access and level playing fields, while taking into account the need for differential treatment commensurate with the

10 See George Anderson, ed., Internal Markets and Multi-level Governance: The Experience of the European Union, Australia, Canada, Switzerland, and the United States (Don Mills: Oxford University Press, 2012). 
needs of subsequent levels of government as they may vary in accordance with different societal and economic structures and levels of development. The allocation is informed by the principle of subsidiarity, that is building governance from below and allocating powers on subsequent levels only to the extent necessary to produce agreed public goods, such as security, enjoyment of human rights, welfare systems, market access and equal conditions of competition. Regulatory powers assigned to superior levels mainly serve the purpose of realizing such goals while otherwise respecting cultural diversity and diverging needs. Such policy space, importantly, is not limited to domestic law but may also be needed on the regional or global level, depending on the public goods to be produced. The fundamentals operating in federacy equally operate within the realm of public international law. There is no fundamental difference in terms of underlying interests and values at stake. On all levels of human governance within the Five Storey House, it is a matter of properly defining policy space for each of the layers of governance alike.

Policy space, in other words, is not a one-way street but depicts the interaction of different layers of governance. Sometimes, there will be a need to strengthen local and domestic powers. Sometimes, it will be necessary to reinforce policy space in public international law and limit local and domestic powers to achieve a particular good and realize a particular value, fairness and justice. Sometimes, it is important to strengthen the role of legislators and sometimes the powers of courts in developing the law. This is true alike in trade and human rights, the subjects of prime interest in this chapter.

Allocation of powers on appropriate levels of governance requires careful consideration of the factual and normative environment within which they operate. The proper allocation of policy space is a factintensive exercise. It does not allow for simple answers. It operates within a pluralist environment and outcomes or is influenced by different political views in the traditions of federalism or unionism. In reality, allocation of policy space often is driven by interests and does not produce optimal results. Such distortions, however, do not alter the basic and neutral functions of policy space in law and regulation.

Indeed, most political debates in federacies and also within the EU are about diverging perceptions on proper allocation of powers in one or the other way. Most configurations allow for different views and are mixed in nature. Allocation of powers is normally a matter of degree, except for clear-cut configurations, such as the prohibition of torture, which does not allow for any policy space for exceptions on the local or national level. The ban expounded on federal and international law levels is absolute. Vice versa, it would seem that there is no room for centralized policy space on 
the regional or international level when it comes to regulate a purely local matter; but absolute powers are difficult to find here because the matter may be partly influenced by overriding concerns and interest, such as the principles of non-discrimination and the protection of minorities. Most configurations therefore are mixed, and it is a matter of defining an appropriate policy mixture in support of best possible results and outcomes.

Policy space not only influences the allocation of powers between domestic and international law, but also affects allocations within these layers. The precepts of regulatory theory indicated above fully apply in regional and international law. Recourse to broadly textured norms and principles of international law increases the policy space of those applying and interpreting the law. Principles of law and human rights entail a broader scope of interpretation than detailed, technical and administrative rules. The former entails delegations of interpretative powers by negotiators and legislators, while the latter seeks to limit policy space by enacting detailed regulation. In WTO law, recourse to broad principles inherently expands powers of panels and the Appellate Body within their mandate in accordance with Article 3(2) of the Dispute Settlement Understanding (DSU) without exceeding the limits imposed by the provision. ${ }^{11}$ The norm is further specified by means of precedents. Principles and provisions entailing policy space inherently comprise an element of activist interpretation within the bounds delegated to the interpreter and those applying the provisions both on the international and national levels. Or, recourse to equity and equitable principles as a normative concept inherently grants policy space to adjudicators. They are called upon to identify appropriate principles, relevant circumstances and factors, and balance those after fact-intensive assessments with a view to produce an equitable solution. Maritime boundary delimitation is the area most advanced in using this methodology. ${ }^{12}$ It is also suitable to apply to other fact-intensive domains, both in international and domestic laws. Policy space is granted to bring about fairness and equity in inherently differing configurations, not suitable to be addressed in terms of rigid rules and exceptions.

Finally, it is important to reiterate that the impact of policy space also affects horizontal relations among states. Granting policy space to

11 World Trade Organization (WTO), Understanding on Rules and Procedures Governing the Settlement of Disputes (Geneva: World Trade Organization), available at https://www.wto.org/english/docs_e/legal_e/28-dsu_e.htm (accessed 3 January 2017).

12 Thomas Cottier, Equitable Principles of Maritime Boundary Delimitation: The Quest for Distributive Justice in International Law (Cambridge: Cambridge University Press, 2015). 
domestic law also allows members to adopt measures which may affect other countries. Countries with large market powers, to which others need to adapt in order to secure market access, will need to adopt measures imposed using policy space granted by international law. Wide policy space thus may be in the interest of large and dominant countries. It is not necessarily in the interest of median and smaller countries depending upon access to large markets. They often benefit from restrictions of policy space by international law, limiting the scope of autonomous action of large jurisdictions. Competition law and policy is an example in point. The lack of disciplines in international law leaves large jurisdictions with the possibility to unilaterally define extraterritorial effects of competition law commensurate to the effects principle. Countries and industries affected are without remedies in international law and exposed to extensive policy space, which is used to protect domestic interests. In trade policy, the limit imposed by international law, for example in the field of trade remedies, protects other nations from overly intrusive measures. It allows them to defend their interests before panels and the Appellate Body of the WTO. Calls for more policy space in domestic law, in particular on the part of smaller nations and developing countries, need to keep this in mind.

\section{TRADE REGULATION}

International trade law is a prime example of the need for carefully protecting policy space on the level of international law to limit preexisting domestic policy space. The history of the interwar period comes to mind and offers a remarkable example of the implications of leaving all policy space on the domestic and national levels. ${ }^{13}$ While trade, in particular tariffs, were historically a matter of exclusive domestic taxation and law, international law increasingly limited domestic policy space in serving market access rights abroad. The process of developing rules on anti-dumping, subsidies and countervailing duties are good examples in point. It was a matter of limiting domestic policy space in order to avoid

13 Charles P. Kindleberger, "Commercial Policy between the Wars" in Peter Mathias and Sidney Pollard, eds, The Cambridge Economic History of Europe from the Decline of the Roman Empire, vol. 8 (Cambridge: Cambridge University Press, 1989) 161; Barry Eichengreen and Douglas A. Irwin, The Slide to Protectionism in the Great Depression: Who Succumbed and Why? National Bureau of Economic Research (NBER) Working Paper 15142 (July 2009), available at http://www.nber. org/papers/w15142 (accessed 3 January 2017). 
protectionist and rent-seeking policies often preferred by constituencies dominated by domestic producer interests. ${ }^{14}$ Domestic policy space was eventually reduced to enhance the interests of consumer welfare and growth of economies. Subsequent generations of agreements refined these boundaries, seeking a proper balance between the interests of competing political entities and economic interests. From early trade agreements to the General Agreements on Tariffs and Trade (GATT) and the WTO, the process can be observed of offsetting protectionist policies exploiting previously existing policy space due to the absence of an international system while recognizing legitimate policy goals and thus appropriate domestic policy space.

More recent periods after the advent of the WTO in 1995 again emphasize the need for domestic policy space in what could be termed a dialectical and historical process of seeking appropriate and balanced relations between international and domestic policy space, commensurate with the needs of the times. Modern areas of law show complex and intertwined structures and interaction of domestic and international law. For example, rules on subsidies in the field of energy need to be redefined in terms of domestic and international policy space. ${ }^{15}$ Financial regulation and capital controls are yet another example in point discussing appropriate policy space on the domestic and international law levels. ${ }^{16}$

The same process of reform can also be observed in refining the law by means of interpretation. The evolution of the case law in GATT and the WTO can be characterized as a process of constitutionalizing the operation of fundamental principles, in particular of national treatment. Under GATT 1947, interpreted in a narrow and functionalist manner in support of trade liberalization, ${ }^{17}$ other public policy goals, mainly in the field of the environment, were neglected and called for larger domestic policy space.

14 See John H. Jackson, World Trade and the Law of GATT (Indianapolis: Bobbs-Merill, 1969) 780.

15 Luca Rubini, “Ain't Wastin' Time No More: Subsidies for Renewable Energy, The SCM Agreement, Policy Space, and Law Reform” (2013) 15:2 Journal of International Economic Law 525; Aaron Cosbey and Petros C. Mavroidis, "A Turquoise Mess: Green Subsidies, Blue Industrial Policy and Renewable Energy: The Case for Redrafting the Subsidies Agreement of the WTO" (2014) 17:1 Journal of International Economic Law 11.

16 Federico Lupo Pasini, "Movement of Capital and Trade in Services: Distinguishing Myth from Reality Regarding the GATS and the Liberalization of the Capital Account" (2012) 15:2 Journal of International Economic Law 581.

17 GATT Panel Report, US - Tuna (Mexico) DS21/R, Circulation Date: 3 September 1991 (not adopted); GATT Panel Report, US - Tuna (EEC) DS29/R, Circulation Date: 16 June 1994 (not adopted). 
The quest for defining "like products" is a process of trial and error and is an example in point. The doctrine of aims and effects, or the doctrine of Processes and Production Methods (PPMs) allowing distinguishing like products as such, was an attempt to increase policy space of Members of the GATT and the WTO. ${ }^{18}$ Likewise the interpretation of the exceptions of Article XX GATT shows a process of enlarging policy space of members, in particular in the field of environmental protection and animal welfare. ${ }^{19}$ Interpreting the Technical Barriers to Trade (TBT) Agreement in a manner to allow for implied exceptions commensurate with the regulatory purposes of the measure is another example in point. ${ }^{20}$ WTO law has come a long way in balancing different interests as equally legitimate interests. ${ }^{21}$ It no longer places market access and liberalization as its sole and main purpose. Trade liberalization has made way for trade regula-

18 This doctrine and jurisprudence, later rejected by the Appellate Body of the WTO, identified violations of national treatment only when like domestic products were intentionally privileged for protectionist purposes or the regulation deployed such effects. For a discussion see Thomas Cottier, Matthias Oesch and Thomas M. Fischer, International Trade Regulation: Law and Policy of the WTO, the European Union and Switzerland: Cases, Materials and Comments (Bern and London: Staempfli Publishers and Cameron May, 2005) 403; US - Taxes on Automobiles, Report of the Panel, 11 October 1994 (not adopted) DS31/R, 33 ILM 1397 (1994).

19 US - Gasoline Appellate Body Report, United States - Standards for Reformulated and Conventional Gasoline, WT/DS2/AB/R, adopted 20 May 1996, DSR 1996:I, p. 3; US - Gasoline Panel Report, United States - Standards for Reformulated and Conventional Gasoline, WT/DS2/R, adopted 20 May 1996, as modified by Appellate Body; US - Shrimp Appellate Body Report, United States - Import Prohibition of Certain Shrimp and Shrimp Products, WT/DS58/ AB/R, adopted 6 November 1998, DSR 1998:VII, p. 2755; US - Shrimp (Article 21.5 - Malaysia) Appellate Body Report, United States - Import Prohibition of Certain Shrimp and Shrimp Products - Recourse to Article 21.5 of the DSU by Malaysia, WT/DS58/AB/RW, adopted 21 November 2001, DSR 2001:XIII, p. 6481 Report WT/DS2/AB/R, DSR 1996:I, p. 29; EC - Measures Prohibiting the Importation and Marketing of Seal Products, WT/DS400/AB/RWT/DS401/AB/R (22 May 2014); EC - Seal Products Panel Reports, European Communities Measures Prohibiting the Importation and Marketing of Seal Products, WT/ DS400/R, WT/DS401/R and Add.1 (25 November 2013).

20 US - Tuna II (Mexico) Appellate Body Report, United States - Measures Concerning the Importation, Marketing and Sale of Tuna and Tuna Products, WT/DS381/AB/R, adopted 13 June 2012; US - Tuna II (Mexico) Panel Report, United States - Measures Concerning the Importation, Marketing and Sale of Tuna and Tuna Products, WT/DS381/R, adopted 13 June 2012, as modified by Appellate Body Report WT/DS381/AB/R.

21 This is the essence of a constitutional approach to treaty interpretation, cf. Thomas Cottier, "Limits to International Trade: The Constitutional Challenge" in The American Society of International Law, ed., International Law in Ferment: A 
tion, not as a matter of undue interventionism but of mainly addressing non-tariff barriers and the legal framework of international trade and investment, both domestically and on the level of international law. ${ }^{22}$ This essentially is a matter of allocating policy space and powers on appropriate levels of governance.

While the principle defines policy space on the international level, the exceptions do so for the national level. Importantly, however, the level is defined by international law, albeit granting deference to national interpretations. This is not a matter of discarding international principles, giving up treaty obligations and returning to unfettered domestic policy space. Calibration of policy space takes place within the existing agreements, and may be further developed by additional provisions and disciplines in the process of international negotiations.

Calling for policy space in domestic law must keep this in mind. Calling for clean and unfettered space beyond international or regional law would turn back to configurations and risks of the interwar period and does not make sense to any rational mind. The abolishment of international trade law disciplines or of regional law advocated for in the political process may produce results opposite to what proponents of a national conservative agenda hostile to multilevel governance, regional and international law promise to their constituencies. Defining domestic policy space inherently remains a matter of shaping and interpreting international law. This implies reviewing existing allocations and making necessary changes. We examine to what extent such changes should be made in light of protecting human rights and local cultural practices in particular.

\section{HUMAN RIGHTS}

The relationship between trade and human rights is a complex one. Historically sharing the same roots, human rights and trade policy developed in completely separate fora and constituencies. ${ }^{23}$ For many years

New Vision for Theory and Practice. Proceedings of the 94th Annual Meeting, 5-8 April 2000. Washington, DC, 2000, pp. 220-2.

22 Thomas Cottier, "International Economic Law in Transition from Trade Liberalization to Trade Regulation" (2014) 17:3 Journal of International Economic Law 671.

23 Ernst-Ulrich Petersmann, "Human Rights and International Economic Law in the 21st Century: The Need to Clarify their Interrelationships" (2001) 4:1 Journal of International Economic Law 3; Thomas Cottier, "Trade and Human Rights: A Relationship to Discover" (2002) 5:1 Journal of International Economic Law 111. 
they have remained mutually disinterested, if not hostile. Efforts were made to overcome dichotomies and to lead to a more coherent interaction and legal relationship. The gradual recognition of legitimate policy goals in the field of the environment also prepared the way for redefining the relationship between trade and human rights. While academic writing and doctrine worked towards greater coherence of trade, investment and human rights, ${ }^{24}$ the fields were increasingly linked in regional and preferential trade agreements. ${ }^{25}$ State practice, however, has hardly developed the relationship so far in trade policy within the WTO. Nor do human rights clauses in preferential trade agreement show much impact. Human rights have played a role in adopting economic sanctions under the umbrella of the United Nations and thus justified by Article XXI GATT. But no single case has yet been brought challenging measures taken to protect human rights under Article XX of the GATT or Article XIV General Agreement on Trade in Services (GATS). Likewise, no case has been brought restricting market access rights due to human rights violations abroad, including labour standards, in particular child labour or even prison labour explicitly provided for in Article XX GATT or Article XIV GATS. In addition, little or no experience to this effect exists in implementing and enforcing preferential trade agreements and labour standards. The jury is still out.

Yet, today, it is safe to say that, building upon existing case law, a WTO member is entitled to restrict trade for the purpose of protecting human rights and labour standards in particular. The same is likely under pref-

24 Ernst-Ulrich Petersmann, International Economic Law in the 21st Century: Constitutional Pluralism and Multilevel Governance of Interdependent Public Goods (Oxford: Hart Publishing, 2012); Frederick M. Abbott, Thomas Cottier and Christine Breining-Kaufmann, eds, International Trade and Human Rights: Foundations and Conceptual Issues (Ann Arbor: University of Michigan Press, 2006); Thomas Cottier, Joost Pauwelyn and Elisabeth Bürgi Bonanomi, eds, Human Rights and International Trade (Oxford: Oxford University Press, 2005); Lorand Bartels, "Trade and Human Rights" in Daniel Bethlehem, Isabelle Van Damme, Donald McRae and Rodney Neufeld (eds), The Oxford Handbook of International Trade Law (Oxford: Oxford University Press, 2009) 571; Gabrielle Marceau, "Trade and Labour" in Bethlehem et al. (ibid.) 539; Drusilla K. Brown, "Labour Standards and Human Rights" in Amrita Narlikar, Martin Daunton and Robert M Stern, eds, The Oxford Handbook on the World Trade Organization (Oxford: Oxford University Press, 2012) 697; Pierre-Marie Dupuy, Francesco Francioni and Ernst-Ulrich Petersmann, eds, Human Rights in International Investment Law and Arbitration (Oxford: Oxford University Press, 2009).

${ }_{25}$ See Emilie Hafner-Burton, "Trading Human Rights: How Preferential Trade Agreements Influence Government Repression" (2005) 59 International Organization 593. 
erential trade agreements, to the extent that they refer to relevant WTO disciplines in terms of policy space. The way panels and the Appellate Body construed and interpreted the concept of public morals in particular allowed taking into account human rights concerns in shaping trade policy today.

Recent case law in 2014 relating to the ban of seal products in the EU essentially relied upon the power of Member States to invoke public morals to essentially justify the import and marketing restrictions under Article XX(a) GATT. ${ }^{26}$ While the notion is one of public international law, panels and the Appellate Body had adopted deferential standards of interpretation before, essentially accepting unilaterally defined perceptions of public morals within a particular constituency. ${ }^{27}$ It has largely and essentially become a matter of domestic policy space with some strings attached in international law. The test applied essentially relies upon a coherent recourse and argumentation based upon public morals and the protection of animal welfare in the political process developing and adopting legislation. Thus, it is not possible to have recourse to public morals in defence of a measure that was introduced upon other grounds in the first place. Recourse to public morals calls for a deliberate decision to invoke the policy space offered on its grounds. The approach was essentially confirmed in 2016 by the Appellate Body in a matter related to money laundering. ${ }^{28}$ The same test can be applied in defence of measures related to labour standards and to human rights standards broadly speaking. Different configurations can be distinguished:

26 EC - Measures Prohibiting the Importation and Marketing of Seal Products (note 19 above).

27 US - United States - Measures affecting the Cross-Border Supply of Gambling and Betting Services, WT/D285/AB/R (7 April 2005). For a discussion see Mark Wu, "Free Trade and the Protection of Public Morals: An Analysis of the Newly Emerging Public Morals Clause Doctrine" (2008) 33 Yale Journal of International Law 215; Eric H. Leroux, "From Periodicals to Gambling: A review of systematic issues addressed by WTO adjudicatory bodies under GATS" in Marion Panizzon, Nicole Pohl and Pierre Sauvé, eds, GATS and the Regulation of International Trade in Services (Cambridge: Cambridge University Press, 2008) 236. For an early assessment of Article XX(a) GATT see Steve Charnovitz, "The Moral Exception in Trade Policy" (1998) 38 Virginia Journal of International Law 689; Nicolas F. Diebold, "The Morals and Order Exceptions in WTO Law: Balancing the Toothless Tiger and the Undermining Mole" (2008) 11:1 Journal of International Economic Law 43.

28 Colombia - Measures Relating to the Importation of Textiles, Apparel and Footwear, WT/DS461/AB/R (7 June 2016). 
(a) A country is in a position to restrict imports of products with a view to defend domestically applied labour and human rights standards. Such measures may take recourse to import restrictions beyond bound tariffs, for example by means of quantitative restrictions or price controls in support of minimal wages imposed on the production of domestic and exported products (goods and services). All measures take effect within the territory of the Member imposing the restriction.

(b) A country is in a position to restrict import products with a view to defend labour standards and human rights not only applied at home, but also sought after in exporting markets. Trade restrictions quantitative restrictions - can be applied, including a total ban on the product with a view to combat practices abroad. The measures deliberately target production practices abroad and are not limited to ancillary effects. It is conceivable to restrict imports the production of which violated labour or human rights standards in the wake of making and processing the products. Public morals, in other words, deploy not only effects within the territory of the Member, but also within the territory of the exporting country.

European Communities - Seal Products did not rule on the contentious issue as to whether WTO allows for recourse to so-called PPMs. The parties did not address the issue, and the Appellate Body left the issue open. ${ }^{29}$ Yet, the ruling in effect does rely upon PPMs - banning methods of killing considered inhuman and thus contrary to public morals. The same configuration also applies to labour standards and human rights based upon the assessment of the domestic regulation adopted generally banning certain practices.

Whether or not such measures are compatible with WTO law will depend on the specific measures taken, assessing whether they are necessary and cannot be replaced by less intrusive instruments achieving the goals of the regulation. Secondly, they need to comply with the requirements of the chapeau of Article XX GATT. This provision essentially protects good faith, preventing abuse of rights and examining whether all parties, where the same conditions prevail, enjoy equal or comparable treatment. The provision also requires that prior to the adoption of measures a negotiated settlement of the issue has been sought with Member States affected by the measure. So far, all measures examined under the umbrella of Article XX GATT have failed to pass the test of the chapeau and have been sent back

29 EC - Measures Prohibiting the Importation and Marketing of Seal Products, (note 19 above) at para. 5.173. 
to the drawing board for improvement, yet without rejecting the lawfulness of such measures in principle. ${ }^{30}$

Policy space for the protection of public morals at home and abroad thus essentially exists. Main problems in terms of policy space and human rights in fact have not arisen under the exception clauses, but in relation to other provisions of WTO law. The right to food was invoked to justify export restrictions under Article XI GATT and the Agreement on Agriculture by India. It led to stalemate and last-minute informal settlement at the Bali Ministerial Conference in 2013, but no changes to WTO law have taken place subsequently. The policy space related to export restrictions of agricultural commodities remains controversial and still awaits a more principled approach. ${ }^{31}$ The second main issue related to policy space is procuring essential drugs, a well-known issue. The rules adopted under the Agreement on Trade-Related Aspects of Intellectual Property Rights (TRIPS), obliging developing countries to adopt patent protection for pharmaceuticals by 2005, limited the export of generic drugs to the world market and to developing countries in particular. Compulsory licensing was not available for exports under Article 31(f) of the TRIPS Agreement, which states that compulsory licensing of patent products shall be authorized predominantly for the supply of the domestic market. The policy space available was too narrow to serve the interests of exporting and importing developing countries. Subsequent negotiations following the adoption of the 2001 Declaration on Public Health led to the adoption of a waiver and eventual revision of the provision. Compulsory licensing was made available under narrowly defined conditions to serve export markets in developing countries. While the waiver of compulsory licensing has not been used often, its very existence contributed to reducing price levels of original HIV products and thus contributed to enhancing affordable supplies to people in need. ${ }^{32}$

\footnotetext{
30 For the case law see note 19 above; for procedural requirements in particular, see US - Shrimp (Article 21.5 - Malaysia).

31 Irene Musselli Moretti, Agricultural Price Stabilization and Trade Rules: A Principled Approach, doctoral thesis adopted by the Faculty of Law of the University of Bern 2016 (on file with author, forthcoming Leiden, Bosten: Brill Nijhoff 2017).

32 See WTO, "TRIPS and public health", available at https://www.wto.org/ english/tratop_e/trips_e/pharmpatent_e.htm (accessed 3 January 2017); WTO, "The separate Doha Declaration explained", available at http://www.wto.org/ english/tratop_e/trips_e/healthdeclexpln_e.htm (accessed 3 January 2017); WTO, "Decision removes final patent obstacle to cheap drug imports" (30 August 2003), available at http://www.wto.org/english/news_e/pres03_e/pr350_e.htm (accessed 3 January 2017); Frederick M. Abbott, "The Doha Declaration on the TRIPS
} 
There may be other areas of WTO law where policy space of developing countries or Members in general is needed to protect human rights and labour standards. The main area under discussion is investment protection. Do existing standards of fair and equitable treatment sufficiently respond to human rights concerns of local populations? Recent developments in doctrine and jurisprudence point towards enhanced policy space for domestic government and law. ${ }^{33}$

The main problem, however, lies elsewhere. Labour standards and human rights protection often suffer from lack of support from domestic law and government. Human rights and the protection of minorities and of labour standards all too often fail to be protected at home under domestic laws and practices. Those dependent on such rights often are not well represented within the domestic political system, and courts of law are not able to protect them on their own. All states risk such failures, and the record of the European Court of Human Rights shows that this also applies to democracies and is not limited to authoritarian governments prevailing in many parts of the world. Governments often are not primarily interested in creating policy space for local communities and practices but in controlling and deterring local autonomy and self-determination. Alternatively, local practices clearly violating human dignity and integrity, in particular the practices of female genital mutilation, remain without legal disciplines and remedies, both in domestic and international law. ${ }^{34}$

Efforts to comply with labour standards and human rights thus depend upon external pressures. Such pressures include, but are not limited to, international trade. Incentives granted may be financial, development assistance or defined in terms of trade measures, and a combination and appropriate policy mixture. Here, it is not a matter of defining policy space of exporting and importing countries or the international community at large in relation to the country concerned with a view to address labour standards and human rights concerns abroad. Such policy space inherently needs to be defined by international law.

It is submitted that additional disciplines in international law are

Agreement and Public Health: Lighting a Dark Corner at the WTO” (2002) 5 Journal of International Economic Law 469.

33 Suzanne A. Spears, "The Quest for Policy Space in a New Generation of International Investment Agreements" (2010) 13:4 Journal of International Economic Law 1037.

34 "Female genital mutilation: An agonising choice" The Economist (18 June 2016), available at http://www.economist.com/news/leaders/21700658-after30 -years-attempts-eradicate-barbaric-practice-it-continues-time-try-new (accessed 3 January 2017). 
required and, thus, enhancing policy space of international law and international institutions. As indicated, main efforts have been made in preferential trade and investment protection agreements, defining the policy space to exert influence and pressure on compliance with human rights standards in exporting countries. ${ }^{35}$ Additional efforts need to be made within the multilateral trading system to this effect. But foremost, the political will to use such policy space needs to be developed.

The first example relates to the protection of labour standards in international trade. While the GATT and GATS rules specifically apply to the treatment of particular products, modern preferential trade agreements allow for trade sanctions for failing respect for labour and human rights standards not specifically related to a product, in particular freedom of association. More recent agreements concluded by the United States contain such clauses. For example, the Regional Trade Agreement (RTA) between the United States and Vietnam allows the United States to withdraw trade concessions to Vietnam upon failure to respect labour standards and freedom of association. Similar provisions form part of the Trans-Pacific Partnership Agreement (TPP) concluded among 12 Pacific countries. The record of such clauses, including withdrawal of the General System of Preferences (GSP) shows some impact on labour conditions, but political will to take recourse to such measures has been limited. ${ }^{36}$ For example, restricting labour practices and the detention of activists in Vietnam are not a matter of the past. ${ }^{37}$ It is thus as much a matter of political will, paying for the costs, for using policy space to foster human rights protection abroad. In light of weak enforcement mechanisms within the International Labour Organization (ILO), enhanced and effective protection of labour standards calls for additional disciplines in international law, reducing domestic policy space and also obliging importing countries to act in case of violations. The approach developed in preferential trade agreements is a first step but does not adequately define policy space in international law.

Another example relates to intellectual property rights (IPRs) and the protection of traditional knowledge (TK). Developing countries seeking to protect economic rights of communities holding traditional

\footnotetext{
35 Hafner-Burton (note 25 above).

36 For an empirical account of US measures see Brown (note 24 above), at $710-14$.

37 "Cash for questions: Can freer trade soften Vietnam's thuggish ways?" The Economist (21 May 2016) at 43, available at http://www.economist.com/news/asia/ 21699162-can-freer-trade-soften-vietnams-thuggish-ways-cash-questions (accessed 3 January 2017).
} 
knowledge, potentially important in bioprospecting and genetic engineering, are impaired from doing so due to minimal standards on patenting new products under the TRIPs Agreement. Members of the WTO and of the World Intellectual Property Organization (WIPO) are discussing the introduction of a transparency obligation to indicate the source and origin of an invention to be protected by patent. Such disclosure will facilitate the identification of prior art potentially denying the novelty of the invention. It will also assist in finding an appropriate agreement between communities and right holders in terms of compensation under rules developed by the Convention on Biodiversity in implementing instruments, most recently the Nagoya Protocol. ${ }^{38}$ Yet, unless international law contains an obligation to recognize traditional knowledge in terms of what I called traditional intellectual property rights (TIPRs) a proper balance on use of, and compensation for, such knowledge is difficult to achieve. ${ }^{39}$ Again, human rights concerns depend, in other words, on more stringent disciplines in international law itself, restricting both users and holders of traditional knowledge.

A third and trade-related example relates to freedom of information. The free flow of information is a prerequisite for the operation of markets and avoidance of distorting asymmetries of information and thus market power. International trade law should make the recognition of freedom of information (perhaps other than freedom of expression) a prerequisite for full market economy status in WTO law.

These examples show that labour standards, human rights protection, economic interests in TK and freedom of information do not depend upon policy space granted to countries, but on appropriate disciplines in public international law itself and the possibility of implementing and enforcing these disciplines by means of international economic law. It is a fallacy to believe that labour standards and human rights are best protected by domestic law and thus by reducing the impact and scope of public international law. To the contrary, effective protection is mainly secured by appropriate disciplines within public international law and its institutions. Such space may need to be wider, or more narrowly construed, depending upon the appropriate allocation of regulatory powers

38 The Nagoya Protocol on Access to Genetic Resources and the Fair and Equitable Sharing of Benefits Arising from their Utilization (ABS) to the Convention on Biological Diversity, available at https://www.cbd.int/abs/about/ default.shtml (accessed 3 January 2017).

39 Thomas Cottier and Marion Panizzon, "Legal Perspectives on Traditional Knowledge: The Case for Intellectual Property Protection" (2004) 7:2 Journal of International Economic Law 371. 
and the possibility of correcting failures produced by particular levels of government.

The finding corresponds to the theory of multi-level governance, which has its foundation in international protection of human rights with a view to correct failings of domestic law and courts to adequately protect individuals and minorities in light of newly emerging challenges. More policy space allocated to national law often results in lower levels of protection of local practices and minorities. Less domestic policy space increases the potential of effective protection, in particular when combined with trade and economic measures linked to the failure to comply with minimal standards set out in public international law.

The same also applies to policy space in the field of international trade. Enhanced domestic policy space may be necessary in particular constellations to support human rights, especially the right to health and the right to food; in other instances, however, it may increase rent-seeking protectionism and lower levels of competition to the detriment of consumers and their interests. It is a matter of correcting such failures by means of recourse to higher-ranking levels of governance within the framework of the Five Storey House. Realization and implementation of human rights in local practices will benefit from such protection by international law.

\section{INTERNATIONAL POLICY SPACE IN HUMAN RIGHTS PROTECTION: A COMMON CONCERN OF HUMANKIND}

The insight that policy space is a neutral concept, equally applying to domestic law and to the realm of international law, and within the different layers, begs the question whether there are configurations where domestic policy space should be excluded or severely limited by international law. Areas may exist not allowing for domestic exemptions.

Likewise, questions of enforcing policy space on the level of international law arise. Responsibilities to realize, specify and implement human rights guarantees primarily lie with domestic law and institutions. This is clearly true for domestic policy space, but also for policy space assumed by levels of regional and international law. Unless these levels develop programmes of their own, such as the EU, regional and international law supports and enforces human rights guarantees within the Five Storey House. While states are supposed to have the power and resources to realize policy space, human rights implementation and enforcement has been notoriously weak on the level of international law. The responsibilities of the international community and other states for 
domestic practices are unsettled and unclear. What are the obligations of states to enforce, and to support, such rights in international law? Can we focus on areas with exclusive policy space in international law? It is submitted that exclusive policy spaces in international law exist, and that realization and enforcement of such spaces is a matter of shared responsibility of the international community under the emerging principle of Common Concerns of Humankind.

In search of exclusive allocations of policy space to international law, disciplines of jus cogens or peremptory norms first come to mind. Fundamental precepts of justice, in particular the prohibition of torture, of apartheid, of refoulement of refugees, and arguably the ban on child labour without providing education, the principle of non-aggression and prohibition of use of force are not only peremptory; they do not leave states and governments policy space as a matter of prohibitions. Being norms ergo omnes, however, they leave policy space and discretion to other subjects of international law in reacting to violations of jus cogens. I argued elsewhere that these fundamental norms of jus cogens form part of Common Concerns of Humankind, and obligations in response to violations should be framed accordingly. ${ }^{40}$

Climate change and biological and cultural diversity have been recognized as a Common Concern of Humankind in treaty law, yet without specifying normative contents and implications. It is submitted that an emerging doctrine and principle of Common Concern of Humankind is also relevant in the present context. We elsewhere defined common concern as a problem affecting more than two states and which cannot be solved alone and in isolation. Climate change is the classical example in point, but by no means limited to it. ${ }^{41}$ Other challenges in international environmental law, such as the depletion and pollution of oceans or keeping international peace and security, come to mind. Common concern relates to the creation of public goods, but is not a public good in itself, but as said before a concern and unresolved issue and problem, which need attention by more than two jurisdictions. Importantly, common concern is not limited to global relations, but applies on all layers of government; common concerns may be limited to a problem shared by two or more local communes in a particular region.

As a normative concept, it is submitted that it entails three types of

40 Thomas Cottier, "Improving Compliance: Jus Cogens and International Economic Law" (2015) 46 Netherlands Yearbook of International Law 329.

41 Thomas Cottier, Philipp Aerni, Baris Karapinar, Sofya Matteotti, Joëlle de Sépibus and Anirudh Shingal, "The Principle of Common Concern and Climate Change" (2014) 52:3 Archiv des Völkerrechts 293. 
obligations: first, to take necessary action at home and within domestic jurisdiction; second, to engage in international cooperation jointly addressing the problem; third, failing action at home or international cooperation, or insufficient efforts made, it allows for unilateral action deploying extraterritorial effect. Again, climate change mitigation is the prime example in point. Due to existing collective action problems and free-riding, unilateral action in the absence of adequate domestic measures, such as carbon taxes, and international cooperation, such as funding and transfer of technology, may eventually take place and impose trade restrictions on products exported from otherwise free-riding jurisdictions. International law thus prescribes obligations to act, but also defines the scope and limits of policy space allocated to states in responding to the problem at hand.

The same approach, it is submitted, can also apply to fundamental human rights and core labour standards. We need to determine to what extent violations of human rights amount to a common concern as described above. First, peremptory norms leaving no policy space to domestic jurisdictions are matters of common concern. Common concern as a concept is more suitable to address the importance of fundamental precepts of justice than the doctrine of jus cogens $v$. jus dispositivum - a distinction which no longer corresponds to modern legal theory and fails to improve the enforcement of basic rights. ${ }^{42}$

Beyond rights traditionally recognized as jus cogens, the question arises to what extent violations of human rights amount to a common concern. As human rights in general offer domestic policy space in terms of exceptions and the pursuit of compelling legitimate public policy interests, the doctrine of common concern cannot apply across the board. States remain free to lawfully restrict the exercise of human rights within the bounds defined by international law and should be protected from intervention. However, violations of what in constitutional law doctrine is termed the core or inalienable content of human rights is suitable to amount to a common concern. It is here that no domestic policy space exists. Violations of the core of rights therefore amount to common concern in terms of threat to international security and the rule of law. This should also comprise protection of children from female genital mutilation.

Rights and obligations of states vis-à-vis violations of jus cogens and the inalienable core of human rights can and should thus be defined by the three categories defined above under the doctrine and principle of common concern. First, states are obliged to honour the rights

42 Cottier (note 40 above). 
domestically and refrain from violating jus cogens and core contents of human rights. They are obliged to cooperate internationally with other states with a view to realizing and implementing such rights. Other states are obliged to take action failing such efforts. The emerging doctrine of Responsibility to Protect (R2P) obliges governments to react in appropriate circumstances. ${ }^{43}$ Policy space is limited to assess appropriate action but no longer leaves room to stay away idly in full discretion.

Common Concern of Humankind, depicting basic and unresolved problems, therefore, stands for the proposition of limiting domestic policy space in the field of human rights protection. Again, it is a matter of addressing state failures and shortcomings with a framework of multilevel governance and appropriate institutions. Trade law and policy thus can play an important role in realizing and enforcing human rights. ${ }^{44}$ As a corollary, it is a matter of limiting policy space for national governments in the field of jus cogens and the core of human rights, rather than expanding it by taking recourse to local practices of human rights and the need for pluralism and variably adapted measures. Obligations to do the homework, to cooperate internationally and to take appropriate unilateral measures are all defined by international law and policy space. Beyond jus cogens and the inalienable core of human rights, states remain free to limit the exercise of human rights for public policy purposes and enjoy domestic policy space - the limits of which should be subject to judicial review by courts of law of preceding levels of governance within the Five Storey House.

\section{CONCLUSION}

While policy space is mainly invoked as a means to increase the scope for domestic action and to limit the impact of international law, regulatory theory suggests using the concept in a neutral manner realizing appropriate allocation of powers to domestic law, international law and among different bodies on layers of governance. Trade and human rights do not unequivocally call for increasing the scope of domestic law, but may also impose the opposite of limiting policy space and leave basic decisions and interpretation of norms within the realm of public international law.

43 Krista Nadakavukaren Schefer and Thomas Cottier, "Responsibility to Protect (R2P) and the Emerging Principle of Common Concern" in Peter Hilpold, ed., Responsibility to Protect (R2P). A New Paradigm of International Law? (Leiden: Brill Nijhoff, 2015) 123.

44 Cottier (note 40 above). 
Violations of rights pertaining to jus cogens and the inalienable core of human rights are a common concern of humankind which triggers obligations to comply, to cooperate and to take unilateral action vis-à-vis failing states. There are others where more policy space is required to operate on the level of public international law within an overall system of vertical checks and balances and the quest of allocating powers to the level and body most suitable to bring about fairness and justice to humans affected. But clearly, human rights do not inherently call for more domestic space. Generally, effective protection of human rights calls for less domestic policy space and stronger guarantees and procedures in international law, taking into account international trade regulation in cooperation and enforcing such disciplines. Trade, human rights and policy space are thus inherently intertwined and need to be dealt with accordingly. 